\title{
THE INFLUENCE OF SERVANT LEADERSHIP STYLE ON MOTIVATION OF BADUNG RESORT POLICE PERSONNEL AND THE MOTIVATION'S IMPACT ON SECURITY CONDITIONS DURING THE CAMPAIGN AND POLLING IN 2018 BALI GOVERNOR ELECTION
}

\author{
I. Gede Agus Ardiyasa, agus.ardiyasa93@gmail.com \\ Indonesian Police Science College
}

\begin{abstract}
Citation : I. Gede Agus Ardiyasa, The Influence Of Servant Leadership Style On Motivation Of Badung Resort Police Personnel And The Motivation's Impact On Security Conditions During The Campaign And Polling In 2018 Bali Governor Election, Management Technology and Security International Journal, page 76-88
\end{abstract}

Received on 6 June 2020, Accepted on 09 July 2020, Published on 1 August 2020

\begin{abstract}
This research aims to investigate the Influence Of Servant Leadership Style On Motivation Of Badung Resort Police Personnel And The Motivation"es Impact On Security Conditions During The Campaign And Polling In 2018 Bali Governor Election. The reserach conducted at Badung Resort using survey for personel. The analasys using multipple regresion linear SPSS 19 with results; 1). Servant leadership style has a positive and significant influence on the motivation of the police personnel in securing the campaigns and polling stations of 2018 Bali governor election at 58.5\%. This means that the motivation of the police personnel in securing the campaigns and polling stations is influenced by servant leadership style as $58.5 \%$ and the rest is influenced by other variables. If the leader applies the right leadership style, it will increase the motivation of his or her members. 2). Servant leadership style and motivation have a positive and significant influence on security conduciveness in securing the campaign activities and polling stations in 2018 Bali governor election in the jurisdiction of Badung Resort Police at $68.4 \%$. This means security conduciveness is influenced simultaneously by serving leadership style and motivation at $68,4 \%$ and the rest is influenced by other variables. 3 ). Servant leadership style has a positive and significant influence on security conduciveness through motivation in securing campaign activities and polling stations in the 2018 Bali governor election in Badung Resort Police jurisdiction at $30.9 \%$. This means security conduciveness is indirectly influenced through motivation by servant leadership style at $30,9 \%$ and the rest is influenced by other factors. Based on these results, the motivational variable can be a positive link between servant leadership style and security conduciveness. From the conclusions above, it can be seen that the security conduciveness can increase even greater if servant leadership style and motivation are jointly applied in carrying out the security duties.
\end{abstract}

Keywords : Servant Leadership, Motivation, Security Conditions, Campaign, Governor Election

\section{INTRODUCTION}

\subsection{Background}

In 2018, there were 171 regions in

Indonesia holding simultaneous regional elections. One of them is Bali Province holding a local election in order to vote for a new governor. The event can be 
considered running smoothly, peacefully, safely and in an orderly manner. This is indicated by the absence of delays and repetition of voting in all districts in Bali. Before the d-day, the community and the candidates as well as their supporters and related agencies had declared a peaceful regional election. Such declaration can be determined as one of the most important factors in keeping the implementation of the elections well. Moreover, the Indonesian National Police (INP) also plays an important role in maintaining security and public order during the election.

Indeed, some jurisdictions or districts in the province had received special attentions because - based on a mapping conducted by Bali General Election Supervisory Agency (Bawaslu) they are vulnerable to potential violations (BeritaSatu.com, 2018). However, with the control from the supervisory agency and security parties, the implementation of the elections in Badung Regency can be carried out well without any violations. Indonesian National Police, in this case Badung Resort Police always takes preventive actions against opportunities that have the potential for violations to occur. Badung Resort Police always does its best actions in order to secure the implementation of the election. The personnel of Badung Resort Police have done their best because they are the major party that are responsible to make sure that the election run smoothly.

Each measure taken by Badung Resort Police in order to secure the event can not be separated from the roles of a leader who can move his members to carry out security duties in order to establish a safe and conducive situation. The leader has an important and, at the same time, complicated tasks. He must be able to manage the organization as well as to be able to show an example in order to to motivate his personnel in implementing the tasks. As a leader, in leading an organization, he must have its own concept of leadership that can encourage its members so that the goals can be achieved. Rivai and Deddy (2012) states "leadership broadly includes the process of influencing in determining the goals of the organization, motivating followers ${ }^{\text {ee }}$ behavior to achieve the goals, and influencing the personnel to improve the group and its culture." Thus, leadership is not only limited to giving instructions, but also to provide motivation that can inspire his or her members.

Motivation is an encouragement that belongs to someone and it is used to do something faster and with better results. Highly motivated members will work with discipline and initiative. They are fully aware that they have the obligations to do their duties or tasks more effectively and efficiently. On the other hand, low motivated members will work with a little discipline and initiative. Such condition will cause delays and disrupt the processes of doing the duties. Such members will be hesitant to attend roll-calls and often complain during the working hours. The portrait can tell us that motivation will impact the way a personnel does his or her duties.

Good performance can be attained if members of an organization have high motivation. In order to be able to become highly motivated members, an organization must be supported by an appropriate leadership style. Such thing occurs in Badung Resort Police in establishing and maintaining security during the campaign and polling of Bali governor election. The members of the resort police take security measures not merely for wanting rewards or praises. They do the duties because they are highly motivated to create conducive situations during the event.

\subsection{Problem Formulation}

1) Does Servant leadership style has positive influence on the 
motivation of the members assigned to secure the execution of campaign and polling stations

2) Does Servant leadership style and motivation of the members assigned has positive influence on secure the implementation of campaign and polling stations

3) Does Servant leadership style influence through the motivation of the members assigned to secure the execution campaign and polling stations

\subsection{Research Purposes}

First, finding out the influence of servant leadership style on the motivation of the members assigned to secure the execution of campaign and polling stations in Bali governor election in the Badung Resort Police. Second, finding out the influence of servant leadership style and motivation of the members assigned to secure the implementation of campaign and polling stations in Bali governor election in the Badung Resort Police on security conduciveness in securing the execution of campaign and polling stations in Bali governor election in Badung Resort Police. Third, finding out the influence of servant leadership style through the motivation of the members assigned to secure the execution campaign and polling stations in Bali governor election in Badung Resort Police on security conduciveness in securing the campaign and polling stations in Bali governor election in Badung Resort Police.

\section{LITERATURE REVIEW}

\subsection{Servant Leadership Style}

Servant leadership style is a leadership model that places service to others as a priority. According to $\mathrm{K}$. Greenleaf (1970) "A servant leader is someone who becomes a servant first. It is starting from the natural feeling that someone who wants to be served, he or she must first serve others. Then, she or he consciously brings someone to lead." Another expert states that a leader who prioritizes services starts with the natural feeling of someone who wants to serve and to prioritize services. Then, the choice consciously brings aspirations and encouragement in leading others (Spears, 2002: 255). Thus, it can be concluded that servant leadership style is a leadership that comes from a sincere sense from the heart to serve, the needs of members are priorities, solving problems together, and providing assistance to members in order to achieve shared goals. In measuring servant leadership style, the research employs the dimensions of servant leadership style proposed by Barbuto \& Wheeler (2006), namely: altruistic calling, emotional healing, wisdom, persuasive mapping, and organizational stewardship.

\subsection{Motivation}

The term motivation comes from the Latin ,movere ${ }^{\text {ee }}$ which means to move. One of theories on motivation is the theory of two factors put forward by Frederick Herzberg. Herzberg in Winardi (2002) states that "motivation is a direct impact of job satisfaction. Job satisfaction and job dissatisfaction come from two factors, namely satisfaction or motivational factors and dissatisfiers or hygiene factors." The motivator factor relates to the nature of the work or content of the work and to the rewards that directly result from carrying out work-related tasks (intrinsic factor). Hygiene factors arise from an individuale $\mathrm{s}$ relationship with the work environment or the work context which are carried out including work policies and administration, supervision, salary, status and working conditions (extrinsic factor). According to Herzberg, salary and benefits are relatively small in influencing work performance of members. But, the overall organizational policies are more likely to influence the motives of members to get high achievement or not. In his two-fact 
theory, Herzberg argues that hygiene (extrinsic) factors have an influence on avoiding dissatisfaction of members' work while motivators (intrinsic) are factors that ensure member job satisfaction in order to further enhance their performance and positive attitudes. Herzberg suggests that it is better to use motivational factors. In addition, because the research respondents are Badung Resort Police personnel who have known the working conditions, salaries, organizational policies, supervision procedures, and status they will receive before they are accepted as police personnel, then the researchers uses indicators of achievement, recognition, work itself , responsibility, progress, development of individual potential.

\subsection{Election Security}

Security can be interpreted as a condition that is free from all forms of disturbances and obstacles. Barry Buzan and Lennen (2009) argues that "security, in an objective sense, is to measure the absence of threats to the values obtained; and in a subjective sense, is the absence of fear that these values will be attacked." According to Djamin (2004), security is a condition or a situation that is free from physical and physical disturbances; life is safe and protected; and properties are free all sorts of threats and dangers." Based on these two concepts, it can be concluded that security means a situation in which there is no fear and it is free from physical and physical threats toward lives and properties of a community. The study emphasizes the safety and security of the community during the execution of the election. Therefore, the researcher focuses on the concept of the mapping of vulnerable areas conducted by Bali Police Region referring to the letter of Bawaslu regarding the Voting Place Vulnerability of 2018 Simultaneous Regional Head Elections. The Bawaslu letter, used by Bali Police Region, determines several vulnerable areas at the time of the elections in Bali. An area will be categorized conducive or not vulnerable if the area does not meet the indicators of hazard dimensions which have been established by Bawaslu. Such dimensions used are money politics, voting, and campaigns.

\section{RESEARCH METHODOLOGY 3.1 Population and Samples}

The population of the study is all Badung Resort Police personnel involved in securing the campaign and polling stations of Bali governor election. They are listed in the decree of the chief of Badung Resort Police Number: Sprin/254/II/OPS 1.3/2018 on February 12, 2018 regarding the Security of the Campaign and the decree of the chief of Badung Resort Police Number: Sprin/938/VI/OPS 1.3./2018 on June 22, 2018 regarding the Security of Polling Stations ("TPS"). The selection of personnel as a population in the study is based on the considerations related to the characteristics of the variables of the research. There are 583 Badung Resort Police personnel who are involved in securing the campaign and polling stations in Bali governor election. The researchers assume that personnel who are assigned the campaign will also assigned in securing the polling stations.

Besides measuring the variables of security conduciveness when securing the campaigns and polling stations in the jurisdiction of Badung Resort Police, the researcher also determines 366,545 people listed in the Permanent Voter List (DPT) of Badung Regency as the population in the study. In order to determine the number of respondents that represent the population the researcher uses Slovin formula as follows:

$$
n=\frac{N}{\mathrm{Ne} 2+1}
$$

Note: 
$\mathrm{n}=$ Sample Size $; \mathrm{N}=$ Total Population $; \mathrm{e}=$ desired critical value, accuracy limit), the error limit is set at $10 \%(0.1)$

Using the Slovin formula, the minimum number of respondents to be taken from a population of 583 is 86 personnel. Meanwhile, in order to take samples from Badung community, the researcher uses the cluster sampling or area sampling by first determining the sub-district area to be taken as a sampling. Then, the researcher selects 15 people in each sub-district.

\subsection{Data Collection Techniques}

Data collection technique used in the study is a survey method by distributing questionnaires to respondents from Badung Resort Police personnel involved in securing the campaigns and polling stations in Bali governor election and selected Badung community. The questionnaire contains several statements of the dimensions of each variable used as follows:

1) Servant leadership variable-using Servant Leadership Questionnaire (SQL) proposed by Barbuto \& Wheeler (2006), namely altruistic calling, emotional healing, wisdom, persuasive mapping, and organizational stewardship.

2) Motivation variable-using the dimension proposed by Herzberg in order to further improve performance and positive attitudes, it is better to use motivational factors. The indicators of the motivational factors are

achievement, recognition, work itselfi,. responsibility, progress, development of individual potential.

3) Election security variables - referring to a letter from the local Bawaslu regarding the mapping of vulnerable areas in Badung Regency. The concepts of dimension used here are money politics, voting and campaigns.

\subsection{Data Analysis Techniques}

The study employs path analysis method to analyse the patterns of relationships between variables. The model is used to determine the direct and indirect influences of the independent variables on the dependent variable. The stages of the process are (1) designing a model based on the concepts and theories in the path diagram; (2) examination the underlying assumptions, namely the linear and additive relationships between variables;

(3) estimating the path coefficient parameters using triming theory; (4) examining the model validation - there are several characteristics, namely recalculating variables that are not significant, refine the model of hypothesized path analysis structure: (5) interpreting the results of "analysis" done by paying attention to the results of the model validity and calculating the total influence of each variable that has a causal influence (one direction) to the dependent variable.

\section{RESULT}

\subsection{Characteristics of Respondents}

There two types of the research respondents used here: Badung Police

Resort personnel and Badung people listed in the DPT. The characteristics of the respondents are presented here in order to see the profile of research data as follows:

Characteristics of Respondents of Badung Resort Police Personnel Age. Based on the results of the questionnaire, it can be seen that nine respondents $(10.5 \%)$ are below 30 years old; 35 respondents $(40.7 \%$ are $30-40$ years old; 26 respondents $(30.2 \%)$ are $41-50$ years old: and 16 respondents $(18.6 \%)$ are above 50 years. This means that most of the respondents of the Badung Police Resort are 30-40 years old. 


\section{1) Gender}

Based on the results of the questionnaire, it can be seen that the number of male respondents is $79(91.9 \%)$ and the number of female respondents is seven $(8.1 \%)$ women. This means that the majority of respondents are male.

\section{2). Status}

Based on the results of the questionnaire, it can be seen that four respondents $(4.7 \%)$ are single and 82 respondents $(95.3 \%)$ are married. This means that most of the respondents of Badung Police Resort are married.

\section{3) Service Duration}

Based on the results of the questionnaire, it can be seen that eight respondents $(9.3 \%)$ have been in service for 3-5 years and 78 respondents $(90.7 \%)$ have been in service for more than six years. This means that most of the respondents of the Badung Police Resort have been in service for more than six years.

\section{4). Education}

Based on the results of the questionnaire, it can be seen that 29 respondents $(33.7 \%)$ graduated from universities and 57 respondents $(66.3 \%)$ graduated from senior high schools. This means that the majority of Badung Resort Police graduated from senior high schools.

\section{5). Experience in Securing an Election}

Based on the results of the questionnaire, it can be seen that seven respondents $(8.1 \%)$ have experience in securing an election once; five respondents (5.8\%) have experience in securing an election twice; and 74 respondents $(86 \%)$ have experience in securing an election more than three times. This means that most of the respondents of Badung Police Resort have experience in securing an election more than three times.

\subsection{Characteristics of Respondents of Badung Community}

1) Age
Based on the results of the questionnaire, it is known that seven respondents $(8.1 \%)$ are below 20 years old; 28 respondents $(15.1 \%)$ are $20-30$ years old; 13 respondents $(15.1 \%)$ are $31-40$ years old; 20 respondents $(23.3 \%)$ are $41-50$ years old; 16 respondents (18.6\%) are 51-60 years old; and two respondents $(2.3 \%)$ are above 60 years old. This means that the majority of respondents from Badung Community are 20-30 years old.

\section{2) Gender}

Based on the results of the questionnaire, it is known that the majority of respondents (41 people/47.7\%) are male and 45 respondents $(52.3 \%)$ are female. This means that most respondents are female.

\section{3) Education}

Based on the results of the questionnaire, it is known that five respondents (5.8\%) graduated from elementary schools; eight respondents $(9.3 \%)$ graduated from junior high schools; 57 respondents $(66.3 \%)$ graduated from senior high schools; nine respondents $(10.5 \%)$ graduated college (D3); and seven respondents (8.1\%) graduated from universities (S1). This means that the majority of respondents graduated from senior high schools.

\section{4) Experience in Securing an election}

Based on the results of the questionnaire, it is known that 15 respondents $(17.4 \%)$ have ever secured an election once; 14 respondents $(16.3 \%)$ have ever secured an election twice; and 57 respondents $(66.3 \%)$ have ever secured an election more than three times. This means that the majority of respondents from Badung community have ever secured an election more than three times.

\subsection{Description of Respondents' Answers}

The section will describe the respondents ${ }^{\text {ee }}$ answers to each variable in the study, as follows:

\section{A. Servant Leadership Style}


The questionnaire on servant leadership style distributed to respondents describes the assessment of Badung Resort Police personnel on how their leader applies the leadership style in serving Badung Resort Police. The dimensions of the questionaire are (1) altruistic calling-putting the interests of others above his personal interests and working hard to meet the needs of his members. The statement is agreed by $85.75 \%$ of respondents; (2) emotional healing-committing to increase and restore the enthusiasm of his members. The statement is agreed by $81.6 \%$ of respondents; (3) wisdom - being easy to understand a situation and itis. impacts. The statement is agreed by $86.6 \%$ of respondents; (4) persuasive mappingpossessing skills to map problems and being able to persuade someone to do something. The statement is agreed by $86.9 \%$ of respondents; and (5) organizational stewardship - being able to prepare his organization to contribute to his environment. The statement is agreed by $89.6 \%$ of respondents.

\section{B. Motivation}

The questionnaire on motivation distributed to respondents describes the motivation of Badung Resort Police personnel in securing the campaigns and polling stations ("TPS") during Bali governor election in the jurisdiction of the resort police. The questionnaire just measures the dimensions of the motivator factors owned by respondents. It consists of (1) achievement, agreed by 89.0 of respondents; (2) Recognition, agreed by $84.1 \%$ of respondents; (3) work itself, agreed by $86.7 \%$ of respondents; (4) responsibility, agreed by $87.2 \%$ of respondents, and (5) progress, agreed by $90.7 \%$ of respondents; and (6)

\section{A. Checking the Assumptions in the Paths}

In the path model used there is a linear and additive relationship between variables, so development of individual potential, agreed by $88.4 \%$ of respondents.

\section{Election Security}

The questionnaire on election security distributed to respondents describes the security situation during the campaigns and polling executions in the jurisdiction of Badung Resot Police. The variable measures (1) voting, agreed by $87.12 \%$ of respondents and (2) campaign, agreed by $88 \%$ of respondents.

\section{DISCUSSION}

\subsection{Designing Track Models}

Based on the concepts and theories applied in the research, the relationships between variables can be modelled in the form of path (see Figure 1):

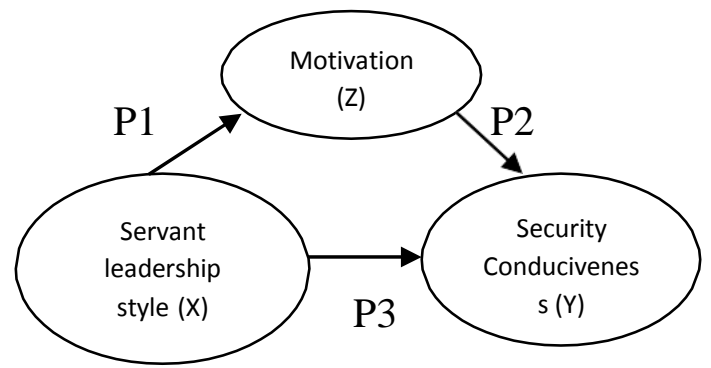

Figure 1 The Pathway Model of the Influence of Servant Leadership Style on Security Conducive With Motivation as the Intervening Variable

From the above model, it can also be stated in the form of an equation, namely:

$\mathrm{Z}=\alpha+\mathrm{P} 1 \mathrm{X} \ldots$.

$\mathrm{Y}=\alpha=\mathrm{P} 3 \mathrm{X}+\mathrm{P} 2 \mathrm{Z} \ldots .$.

\subsection{Path Analysis}

Research data in this study is analysed in order to examine the patterns of relationships between the variables. This analysis is carried out in the following stages:

that the relationship system between variables has a one-way or causal flow in accordance with the concepts and theories applied in this study. And there are no 
endogenous variables that have an alternating influence.

B. Estimating the Parameters of the Path Coefficient

In this stage divides the calculation into direct influences, indirect influences and total influences. For direct influences expressed by looking at the results in the calculation results table with the SPSS application, while for indirect influences and total influences can be made their own calculations. In estimating the path coefficient parameters, a regression analysis is carried out with the help of the SPSS application, to obtain the following results:

\section{A. Sub-structure I: $Z=\alpha+P 1 X$}

From the results of testing the data on the SPSS application the results are obtained:

Table 1: Regression Sub-Structure I

\begin{tabular}{|c|c|c|c|c|}
\multicolumn{9}{|c|}{ Summary Model } \\
\hline Model & $\mathbf{R}$ & $\begin{array}{c}\text { R } \\
\text { Square }\end{array}$ & $\begin{array}{c}\text { Adjusted R } \\
\text { Square }\end{array}$ & $\begin{array}{c}\text { Std. Error of the } \\
\text { Estimate }\end{array}$ \\
\hline 1 & $.765^{\mathrm{a}}$ & .585 & .581 & 7.24227 \\
\hline
\end{tabular}

a. Predictors: (Constant), Serving Leadership Style $(X)$

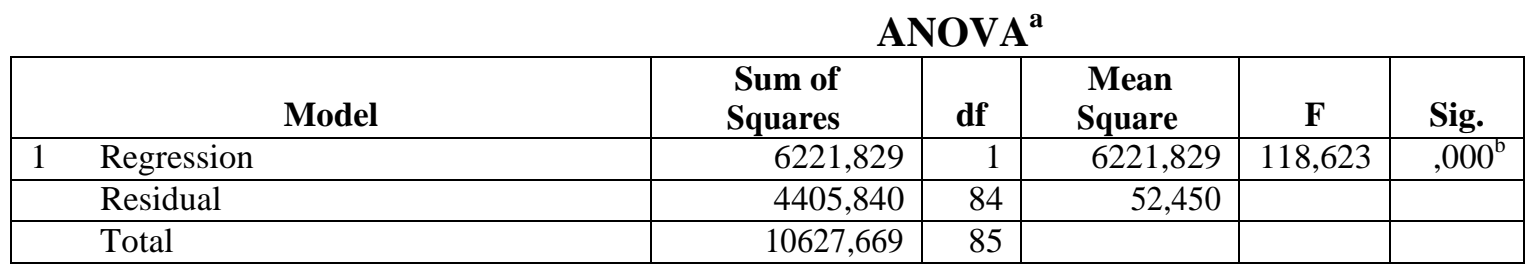

a. Dependent Variable: Motivation (Z)

b. Predictors: (Constant), Serving Leadership Style (X)

Coefficients $^{\mathrm{a}}$

\begin{tabular}{|c|c|c|c|c|c|}
\hline \multirow[b]{2}{*}{ Model } & \multicolumn{2}{|c|}{$\begin{array}{c}\text { Unstandardized } \\
\text { Coefficients }\end{array}$} & \multirow{2}{*}{$\begin{array}{c}\begin{array}{r}\text { Standardized } \\
\text { Coefficients }\end{array} \\
\text { Beta }\end{array}$} & \multirow[b]{2}{*}{$\mathbf{t}$} & \multirow[b]{2}{*}{ Sig. } \\
\hline & B & Std. Error & & & \\
\hline \multirow{4}{*}{$\begin{array}{l}\text { (Constant) } \\
\text { Servant Leadership Styl }\end{array}$} & 9,761 & 2,796 & & 3,491 & ,001 \\
\hline & & & & & \\
\hline & ,752 & ,069 & ,765 & 10,891 & ,000 \\
\hline & & & & & \\
\hline
\end{tabular}

a. Dependent Variable: Motivation (Z)

B. Sub-structure II: $=\mathrm{Y}=\alpha+\mathrm{P} 3 \mathrm{X}+\mathrm{P} 2 \mathrm{Z}$

From the results of testing the data on the SPSS application the results are obtained:

Table 2: Regression of Sub-Structure II

Summary Model

\begin{tabular}{|c|c|c|c|c|}
\hline Model & $\mathbf{R}$ & R Square & $\begin{array}{l}\text { Adjusted R } \\
\text { Square }\end{array}$ & $\begin{array}{l}\text { Std. Error of the } \\
\text { Estimate }\end{array}$ \\
\hline 1 &, $644^{\mathrm{a}}$ & ,415 & ,401 & 6,57113 \\
\hline
\end{tabular}

a. Predictors: (Constant), Motivation (Z), Serving Leadership Style (X) 


\begin{tabular}{|c|c|c|c|c|c|c|}
\hline \multicolumn{7}{|c|}{ ANOVAa } \\
\hline & Mod & Sum of Squares & df & Mean Square & $\mathbf{F}$ & Sig. \\
\hline 1 & Regression & 2538,999 & 2 & 1269,499 & 29,400 &, $000^{\mathrm{b}}$ \\
\hline & Residual & 3583,918 & 83 & 43,180 & & \\
\hline & Total & 6122,916 & 85 & & & \\
\hline
\end{tabular}

Coefficients $^{\mathrm{a}}$

\begin{tabular}{|c|c|c|c|c|c|}
\hline \multirow[b]{2}{*}{ Model } & \multicolumn{2}{|c|}{$\begin{array}{c}\text { Unstandardized } \\
\text { Coefficients }\end{array}$} & \multirow{2}{*}{$\begin{array}{c}\begin{array}{c}\text { Standardized } \\
\text { Coefficients }\end{array} \\
\text { Beta } \\
\end{array}$} & \multirow[b]{2}{*}{$\mathbf{t}$} & \multirow[b]{2}{*}{ Sig. } \\
\hline & B & Std. Error & & & \\
\hline \multirow{4}{*}{$\begin{array}{ll}1 & \text { (Constant) } \\
& \text { Servant Leadership Style }(\mathrm{X}) \\
& \text { Motivation }(\mathrm{Z})\end{array}$} & 11,794 & 2,715 & & 4,344 &, 000 \\
\hline & ,209 & ,097 & ,280 & 2,145 &, 035 \\
\hline & & & & & \\
\hline & ,307 & ,099 & ,404 & 3,099 &, 003 \\
\hline
\end{tabular}

a. Dependent Variable: Security Conduciveness (Y)

Based on the results of the calculations of sub-structure I and sub-structure II, it can be seen that the magnitude of the direct influence, indirect influence and the total influence between variables are as follows:

\section{a) Direct Influence}

The magnitude of the influence of the servant leadership style on motivation as well as the partial influence of the servant leadership style and motivation on security conduciveness can be seen from the beta value in the unstandardized coefficients table, namely:

1) The influence of servant leadership style (X) on Motivation (Z)

$\mathrm{X} \longrightarrow \mathrm{Z}=0.752$

2) The influence of Servant leadership style (X) on Security Conduciveness (Y)

$\mathrm{X} \longrightarrow \mathrm{Y}=0.209$

3) The Influence of Motivation ( $\mathrm{Z}$ ) on Security Conduciveness (Y)

$\mathrm{Z} \longrightarrow \mathrm{Y}=0.307$

\section{b) Indirect Influences}

The magnitude of the influence of the servant leadership style variable on security conduciveness can indirectly be calculated by multiplying the magnitude of the influence of the servant leadership style (X) on motivation (Z) and the magnitude of the influence of motivation (Z) on security conduciveness (Y). So the calculation is as follows

The influence of servant leadership style

(X) on security conduciveness indirectly:

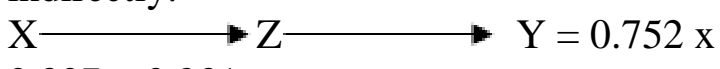

$0.307=0.231$

\section{c) Total Influence}

The magnitude of the total influence is calculated by adding up the direct influence and indirect influence, namely: Total influence $=$ direct influence + indirect influence

$$
\begin{aligned}
& =0.752+0.209+0.307+0.231 \\
& =1,499
\end{aligned}
$$

\section{d). Model validation check}

The researcher uses triming theory in order to check the validity of the model. It is done by removing the non-significant paths in order to get a valid model. In validation testing on each path, we see the value of $p$-value. A model can produce a valid relationship, if the value of $p$-value < 0.05 . From the results of calculations using the SPSS application above, it can be seen that each p-value: the influence of servant leadership style $(\mathrm{X})$ on motivation $(\mathrm{Z})$ is 
0,000 ; the influence of servant leadership style $(\mathrm{X})$ on security conduciveness $(\mathrm{Y})$ is 0.035; and the influence of motivation $(\mathrm{Z})$ on security conduciveness $(\mathrm{Y})$ is 0.003 . Based on these results, it can be seen that the value of $p$-value $<0.05$ so it can be said that the path model used is valid.

\section{e). Model Interpretation}

The influence of each variable partially can be used to test the hypothesis formulation (hypothesis testing):

\section{(1) The Influence of Servant}

\section{Leadership Style on Motivation}

Hypothesis Formulation used:

a. Ho: There is no influence of the servant leadership style on motivation.

b. Ha: There is an influence of servant leadership style on motivation.

With the following test criteria:

a. If Sig $\mathrm{t}<0.05$, then $\mathrm{Ha}$ is accepted and Ho is rejected.

b. If Sig t $>0.05$, then Ho is accepted and Ha is rejected.

From the results of the calculations using SPSS, the significance level of leadership style serving variable is obtained to motivation at $0,000<0.05$. Therefore, $\mathrm{Ha}$ is accepted and $\mathrm{Ho}$ is rejected and there is an influence of servant leadership style on motivation.

\section{(2) The Influence of Serving} Leadership Style and Motivation on Security Conduciveness.

Hypothesis Formulation used:

a. Ho: There is no influence of servant leadership style and motivation on security conduciveness.

b. Ha: There is an influence of servant leadership style and motivation on security conduciveness.

With the following test criteria:

a. If Sig $\mathrm{t}<0.05$, then $\mathrm{Ha}$ is accepted and Ho is rejected.

b. If Sig $\mathrm{t}>0.05$, then Ho is accepted and $\mathrm{Ha}$ is rejected
From the results of the calculations using SPSS, the significance level of servant leadership style variable to security conduciveness is $0.035<0.05$, and the significance of the motivation variable to security conduciveness is $0.003<$

0.05 . Therefore, Ha is accepted and Ho is rejected and there is an influence of servant leadership style and motivate on security conduciveness.

(3) The Influence of Serving Leadership Style on Security Conduciveness through Motivation.

Hypothesis Formulation used:

a. Ho: There is no influence of servant leadership style on security conduciveness through motivation.

b. Ha: There is an influence of servant leadership style on security conduciveness through motivation.

With the following test criteria:

a. If Sig $\mathrm{t}<0.05$, then $\mathrm{Ha}$ is accepted and $\mathrm{Ho}$ is rejected

b. If $\operatorname{Sig} \mathrm{t}>0.05$, then Ho is accepted and $\mathrm{Ha}$ is rejected

From the results of the calculations using SPSS, the significance level of servant leadership style variable to motivation is $0,000<0.05$, and the significance of motivation variable to security conduciveness is $0.003<0.05$. Therefore, $\mathrm{Ha}$ is accepted and Ho is rejected and there is an influence of servant leadership style on security conduciveness through motivation.

\section{4). The Influences of Servant Leadership Styles on Motivation.}

In the regression calculation of substucture I, it can be seen that the value of the $r$ square of servant leadership style variable on motivation variable is 0.585 with a significance level of $0,000<0.05$. This means that servant leadership style influences motivation by $58.5 \%$ and the rest is influenced by other variables. Based on the results of testing the hypothesis, it is 
found that servant leadership style has a positive and significant influence on motivation. Thus, hypothesis $\mathrm{Ha}$ is accepted and Ho is rejected. Thus, if servant leadership style can be applied in an appropriate and correct way, Badung Resort Police personnel will have a high motivation in carrying out their duties in securing the campaign and polling in 2018 Bali governor election.

This is consistent with the results of a research conducted by Nelly F. M. Lucyani Dumatubun (2018) which states that the servant leadership style has a positive and significant impact on motivation. By implementing the servant leadership style, a leader can increase the work motivation of his or her subordinates. However, the results differ from a study conducted by Rozika, Dharma and Sitorus (2018). The study entitled "Servant Leadership, Personnel's Job Satisfaction: The Role of Organizational Culture and Human Resources Practices" finds out that servant leadership style has a negative influence on dependent variable (organizational culture). This makes the researcher employs another different dependent variable, namely motivation. It is expected that servant leadership style can become a way for leaders in order to increase the motivation of their members.

\section{The Influence of Servant Leadership Style and Motivation on Security Conduciveness.}

Based on the regression calculation of substructure II, it can be seen that the value of the beta of servant leadership style and motivation variables to security conduciveness are respectively: the beta value of servant leadership style to the security conduciveness is 0.280 with a significance level of $0.035<0.05$, and the beta value of motivation to security conduciveness is 0.404 with a significance level of $0.003<0.05$. Therefore, the beta value of servant leadership style and motivation variables that simultaneously influence the security conduciveness equals to 0.684 . This means servant leadership style and motivation influence security conduciveness by $68.4 \%$ and the rest is influenced by other variables. Then, the result of testing the hypothesis is that servant leadership style and motivation have a positive and significant influence on security conduciveness. Thus, hypothesis $\mathrm{Ha}$ is accepted and $\mathrm{Ho}$ is rejected. If servant leadership style is applied appropriately and correctly together with the high motivation of the members, they will create a high level of security conduciveness in carrying out the security tasks in the campaigns and polling stations of 2018 Bali governor election the jurisdiction of Badung Resort Police.

The result is in accordance with the result of research conducted by Rozika, Dharma and Sitorus (2018). The study entitles "Servant Leadership, Personnel's Job Satisfaction: The Role of Organizational Culture and Human Resources Practices." It finds out that servant leadership style and training human resources have a positive influence on job satisfaction. If servant leadership style is applied together with other variables in influencing a dependent variable, they will have a positive and significant influence. Another study conducted by Basthoumi Muslih (2012) also states that motivation influences employees $^{\text {ee }}$ performance. In this study, employee performance can be seen from the results of the implementation of the tasks performed by Badung Resort Police personnel in securing the campaigns and polling stations of the election. This evidences also agree with Ammons, D. and McLaughlin, T. (2017).

\section{CONCLUSION}

Based on the results of the discussion and the results of the analysis of the research data above, can be concluded that: 
1) Servant leadership style has a positive and significant influence on the motivation of the police personnel in securing the campaigns and polling stations of 2018 Bali governor election at $58.5 \%$. This means that the motivation of the police personnel in securing the campaigns and polling stations is influenced by servant leadership style as $58.5 \%$ and the rest is influenced by other variables. If the leader applies the right leadership style, it will increase the motivation of his or her members.

2) Servant leadership style and motivation have a positive and significant influence on security conduciveness in securing the campaign activities and polling stations in 2018 Bali governor election in the jurisdiction of Badung Resort Police at $68.4 \%$. This means security conduciveness is influenced simultaneously by serving leadership style and motivation at $68,4 \%$ and the rest is influenced by other variables.

3) Servant leadership style has a positive and significant influence on security conduciveness through motivation in securing campaign activities and polling stations in the 2018 Bali governor election in Badung Resort Police jurisdiction at $30.9 \%$. This means security conduciveness is indirectly influenced through motivation by servant leadership style at $30,9 \%$ and the rest is influenced by other factors. Based on these results, the motivational variable can be a positive link between servant leadership style and security conduciveness. From the conclusions above, it can be seen that the security conduciveness can increase even greater if servant leadership style and motivation are jointly applied in carrying out the security duties.

\section{IMPLICATION}

Based on the results of the research, it is suggested that:
1) Badung Resort Police administrators need to increase and restore the enthusiasm of their members in working to further increase their motivation so that it can have an impact on their performance that can be felt by community in maintaining security and public order;

2) Badung Resort Police administrators need to better prepare the organization to contribute to together with community by improving their members ${ }^{\text {ee }}$ abilities through training to better secure the jurisdiction;

3) Badung Resort Police administrators must know the factors that can influence the security conduciveness in their jurisdiction in order to make policies in maintaining security and public order so that they can quickly make decisions if there is a situation that can disrupt the security conduciveness;

4) Further research activities need to be carried out on security conduciveness using other variables such as the amount of incentives and improving the quality of human resources using the path analysis research model.

\section{REFERENCES:}

Ammons, D. and McLaughlin, T. (2017) Discovering Servant Leader Relations with New Followers in Nonprofit Organizations: Does a Servant Leader Always Serve First?. Open Journal of Leadership, $\mathbf{6}$, 34-60. doi: 10.4236/oj1.2017.62003.

Barry Buzan and Lenen Hansen, 2009, The Evolution of International Security Studies, (United Kingdom: Cambridge University Press, 2009) page. 10-13.

Barbuto, J.E.\& Wheeler, D.W.(2006).Scale development and construct clarification of servant leadership [Electronic Version], Group 
and Organization Management, 31, 300-326.

Djamin Awaloedin et al (2004), "Sejarah Perkembangan Kepolisian di Indonesia ": Dari Zaman Kuno sampai sekarang

Greenleaf, R. K. (1970). The servant as leader. Robert K. Greenleaf Publishing Center.

Nelly F. M. Lucyani Dumatubun (2018), Pengaruh Leadership terhadap Motivasi Kerja, Kinerja Karyawan dan Komitmen Organisasi, Tesis Program Studi Magister Manajemen Universitas Sanatha Dharma, Yogyakarta

Rozika, Dharma and Sitorus (2018), Servant Leadership, Personnele's Job Satisfaction: The Role Of Organizational Culture And Human Resources Practices, Journal of Economic Studies, Faculty of Finance, Banking and Accountancy Bucharest, "Dimitrie Cantemir" Christian University Bucharest, vol. 4(2), pages $120-137$

Rivai, Veithzal dan Deddy Mulyadi. 2012. Kepemimpinan dan Perilaku Organisasi Edisi Ketiga. Jakarta : PT. Rajagrafindo Persada.

Spears, L.C. 2002. On character and servant leadership: Ten characteristics of effective, caring leaders. from http://www.greenleaf.org/leadership/rea daboutit/ ServantLeadership

ArticlesBook-Reviews.html.

Winardi, J. (2002), "Motivasi \& pemotivasian dalam manajemen Judul: Motivasi \& pemotivasian , Jakarta : Raja Persada Grafindo

\section{Regulation:}

Republik Indonesia , 2002, UndangUndang Nomor 2 Tahun 2002 tentang Kepolisian Negara Republik Indonesia. 